\title{
DESKRIPSI USAHATANI TANAMAN BUMBU MASAK "RAMPA-RAMPA CAMPUR" DAN SALURAN PEMASARAN DI DESA SEA DAN KOTA MANADO
}

\author{
Soleman Yapri \\ Nordy F. L. Waney \\ Jen Tatuh
}

\begin{abstract}
This study aims to describe the cultivation of seasoning plants "rampa-rampa mix" and marketing channels that occur in the Village Sea and the city of Manado. This research was conducted in September 2016 until October 2016. The data used are primary data and secondary data. The primary data collection was conducted by direct interview technique with 40 (forty) respondents in this case seasoning plants "rampa-rampa campur" and also using written data in the form of documents obtained from the village head. The data obtained was analyzed using descriptive analysis and presented in the form of story or table. The results of this study indicate that the average profit of cooking season is Rp.461.104 in 1 (one) time to make a sale.
\end{abstract}

Keywords: seasoning plants (rampa-rampa campur), marketing channels, Sea Village, Manado City

\begin{abstract}
ABSTRAK
Penelitian ini bertujuan untuk mendeskripsikan usahatani tanaman bumbu masak "ramparampa campur" dan saluran pemasaran yang terjadi di Desa Sea dan Kota Manado. Penelitian ini dilaksanakan pada bulan September 2016 hingga Oktober 2016. Data yang digunakan adalah data primer dan data sekunder. Pengumpulan data primer ini dilakukan dengan teknik wawancara langsung dengan 40 (empat puluh) orang responden dalam hal ini petani bumbu masak "rampa-rampa campur" dan juga menggunakan data sekunder dalam bentuk dokumen yang diperoleh dari kepala desa. Data yang diperoleh dianalisis mengunakan analisis deskriptif dan disajikan dalam bentuk cerita maupun tabel. Hasil penelitian ini menunjukkan bahwa ratarata keuntungan pasaran bumbu masak adalah sebesar Rp.461.104 dalam 1 (satu) kali melakukan penjualan.
\end{abstract}

Kata kunci: Usahatani, Tanaman Bumbu Masak (Rampa-Rampa Campur), Saluran Pemasaran, Desa Sea, Kota Manado. 


\section{PENDAHULUAN}

\section{Latar Belakang}

Indonesia dari segi geografis merupakan Negara agraris yang penduduknya memahami pertanian secara luas. Penelaahan sumber daya alam (SDA) dan sumberdaya manusia (SDM) yang berkaitan dengan bidang pertanian akan mendorong pembangunan pertanian yang terintegrasi dari hulu (On Farm) sampai ke hilir (Of Farm) yang prospektif untuk meningkatkan kesejahteraan masyarakat. Komponen bidang usahan dapat dikembangkan dengan memanfaatkan peluang kebijakkan pertanian yang dirumuskan oleh pemerintah. Rempah-rempah adalah bagian tumbuhan yang digunakan sebagai bumbu, penguat cita rasa, pengharum, dan pengawet makanan yang digunakan secara terbatas (FAO, 2005 dalam Hakim, 2015).

Hasibuan (2011), mengungkapkan bahwa bumbu adalah bahan baku penyedap masakan yang digunakan sebagai sumber cita rasa dan aroma pada masakan. Pemerintah dapat bekerja sama dengan petani secara langsung sebagai kunci keberhasilan, agar dapat mengembangkan usahatani bumbu masakan diantarannya kemangi, serei, pandan, daun jeruk, dan kunyit. Tanaman bumbu masakan "rampa-rampa campur" selalu menjadi pilihan utama dalam masakan di Sulawesi Utara masakan Manado hampir semua menggunakan "rampa-rampa campur" mulai dari ikan kuah asam, aneka daging, ikan woku, bumbu RW, bubur Manado (Tinutuan) dan lain sebagainya. Dalam meracik bumbubumbu woku dan bumbu kuah asam, "rampa rampa campur" tinggal ditambahkan cabe, bawang, jahe dan kunyit. Untuk racikan bumbu RW, "rampa-rampa campur" (non kemangi) ditambahkan dengan cabe, bawang, lengkuas, jahe dan kunyit, Sedangkan untuk memasak bubur Manado (Tinutuan), "rampa rampa campur" tinggal tambahkan bahanbahan komponen bumbu dan aneka sayuran lainnya. Sayuran tumis Manado tidak lepas dari peran "rampa-rampa campur" seperti tumis kangkung, bunga pepaya, pakis, daun melinjo dan lain sebagainya. Semuanya menggunakan "rampa-rampa campur" dan ditambahkan dengan bumbu non daun lainnya. Orang luar Manado akan kebingungan jika membaca tulisan "RRC" yang terpampang di daftar harga di area sayuran dalam supermarket. "Rampa-rampa campur" yang popular di Manado, membuatnya seolah-olah semua orang sudah tahu bahwa "RRC" adalah "rampa-rampa campur".

Nurramdhani (2009), mengungkapkan bahwa "rampa-rampa campur" merupakan suatu kemasan bumbu daun dan batang yang di dalamnya berisikan daun kemangi, batang serai, daun pandan, daun jeruk, dan daun kunyit. Pemerintah di setiap daerah sedang berupaya untuk mengembangkan usahatani tanaman bumbu masakan agar dapat menjawab permintaan pasar. Satu diantara daerah yang menerapkannya adalah Kabupaten minahasa karena tingkat kosumsi di daerah tersebut tinggi. Masyarakat minahasa memiliki kebiasaan memasak makanan menggunakan bumbu yang lengkap dalam berbagai menu masakan tradisional maupun modern. Pemerintah minahasa dalam hal meningkatkan pendapatan masyarakat berupaya untuk meningkatkan pembangunan pertanian salah satunya di Desa Sea Kecamatan Pineleng. Pada penelitian ini, peneliti akan melihat pola usahatani yang terjadi di Desa Sea. Mulai dari jenis lahan yang digunakan, teknis pengolahan usahatani, pemeliharaan, panen, saluran atau tingkat pemasaran yang di lalui oleh pihak petani sebagai produsen maupun pengecer. Peneliti juga ingin melakukan penelitian mengenai harga jual di tingkat petani ke konsumen akhir, petani ke pedagang pengumpul, pedagang pengumpul ke pengecer, dan pengecer ke konsumen akhir. di Desa Sea dan Kota Manado.

\section{Rumusan Masalah}

1. Bagaimana usahatani tanaman bumbu masakan yang dikembangkan oleh petani di Desa Sea, Kecamatan Pineleng, Kabupaten Minahasa?

2. Berapa besar biaya usahatani yang di keluarkan petani selama proses usahatani dilakukan oleh petani di Desa Sea, Kecamatan Pineleng, Kabupaten Minahasa? 
3. Bagaimana produksi dan pemasaran bumbu masakan "rampa-rampa campur" yang dilakukan oleh petani di Desa Sea, Kecamatan Pineleng, Kabupaten Minahasa?

4. Berapa besar biaya pemasaran yang di keluarkan pelaku pemasar selama proses pemasaran dilakukan oleh petani hingga ditingkat pengecer di Desa Sea, dan Kota Manado.?

5. Berapa besar pendapatan yang didapatkan oleh setiap pelaku pemasar mulai dari petani sebagai produsen hingga tingkat pengecer dari hasil pasaran bumbu masakan"rampa-rampa campur" di Desa Sea, dan Kota Manado?

\section{Tujuan Penelitian}

1. Mendeskripsikan usahatani tanaman bumbu masakan "rampa-rampa campur" yang diterapkan oleh petani di desa Sea, kecamatan Pineleng, kabupaten Minahasa.

2. Mendeskripsikan biaya usahatani yang di keluarkan petani selama proses usahatani dilakukan oleh petani di Desa Sea, kecamatan Pineleng, Kabupaten Minahasa.

3. Mendeskripsikan pemasaran bumbu masakan "rampa-rampa campur" oleh petani di desa Sea ke konsumen di kota Manado.

4. Mendeskripsikan biaya pemasaran yang di keluarkan pelaku pemasar selama proses pemasaran dilakukan oleh petani sebagai produsen hingga tingkat pengecer di Desa Sea, dan kota manado?

5. Menganalisis pendapatan petani hingga tingkat pengecer dari hasil pasaran bumbu masakan "rampa-rampa campur" di Desa Sea, dan kota manado.

\section{Manfaat Penelitian}

1. Menambah pengetahuan mengenai proses penerapan usahatani tanaman bumbu masakan "rampa-rampa campur" dan proses pemasarannya.

2. Memberikan informasi mengenai upaya peningkatan dan perbaikan usahatani tanaman bumbu masakan"rampa-rampa campur" dan pemasarannya.
3. Memberikan informasi mengenai cara penerapan usahatani dan pemasaran tanaman bumbu masakan "rampa-rampa campur" di desa Sea, kecamatan Pineleng, Kabupaten Minahasa.

\section{METODOLOGI PENELITIAN}

\section{Waktu dan Tempat Penelitian}

Penelitian ini dilakukan di Desa Sea, Kecamatan Pineleng, Kababupaten Minahasa, mulai dari bulan Agustus sampai September 2016.

\section{Metode Pengumpulan Data}

Metode pengumpulan yang digunakan adalah metode survey yakni data primer dan data sekunder. Data primer merupakan data yang langsung diperoleh dari petani yang menerapkan usahatani tanaman bumbu masakan "rampa-rampa campur" di Desa Sea. Data sekunder merupakan data yang diperoleh dari bebarapa sumber diantaranya dari pemerintah Desa Sea, sumber data lainnya diperoleh dari buku-buku tentang rempah dan bumbu masakan juga dari jurnal.

\section{Deskripsi dan Pengukuran Variabel Penelitian}

1. Mendeskripsikan usahatani dari masingmasing tanaman yang termasuk dalam kelompok bumbu masakan "rampa-rampa campur".

2. Mendeskripsikan biaya usahatani dari masing-masing tanaman bumbu masakan "rampa-rampa campur".

3. Mendeskripsikan saluran pemasaran bumbu masakan "rampa-rampa campur"

4. Mendeskripsikan Pemasaran bumbu masakan "rampa-rampa campur".

5. Mendeskripsikan besarnya pendapatan yang diperoleh petani bumbu masak "rampa-rampa campur."

\section{Metode Analisis Data}

Analisis data yang digunakan dalam penelitian ini adalah Metode Analisis Deskriptif, yakni akan menguraikan ataupun 
mendeskripsi secara detail tentang aktifitas usahatani sampai pemasaran tanaman bumbu masakan "rampa-rampa campur" di Desa Sea, Kecamatan Pineleng, Kabupaten Minahasa.

\section{HASIL DAN PEMBAHASAN}

\section{Profil Desa Sea}

Desa Sea merupakan salah satu desa dari 14 desa yang berada di Kecamatan Pineleng Kabupaten Minahasa. Secara umum, Desa Sea memiliki luas lahan \pm 552 ha dengan memiliki 7 dusun (jaga). Adapun batas-batas wilayah di Desa Sea sebagai berikut :

a. Sebelah utara berbatasan dengan Desa Sea I, dan Desa Sea II

b. Sebelah timur berbatasan dengan Desa

c. Warembungan

d. Sebelah Selatan berbatasan dengan hutan

e. Sebelah barat berbatasan dengan Desa Koha, dan Desa Kalasey II

\section{Keadaan Penduduk}

Desa Sea memiliki jumlah penduduk 4815 jiwa dengan jumlah 1.637 kepala keluarga. Komposisi penduduk Desa Sea dapat dilihat pada Tabel 1 berikut ini:

Tabel 1. Jumlah Penduduk Desa Sea Berdasarkan Jenis Kelamin

\begin{tabular}{ccr}
\hline $\begin{array}{c}\text { Jenis } \\
\text { Kelamin }\end{array}$ & $\begin{array}{c}\text { Jumlah } \\
\text { (Jiwa) }\end{array}$ & \multicolumn{1}{c}{ Presentase (\%) } \\
\hline Laki-laki & 2,310 & 47,975 \\
Perempuan & 2,505 & 52,025 \\
\hline Jumlah & 4,815 & 100 \\
\hline
\end{tabular}

Sumber : Diolah Dari Buku Induk Desa Sea 2015

\section{Mata Pencaharian Penduduk di Desa Sea}

Penduduk yang berada di Desa Sea memiliki pekerjaan yang berbeda-beda diantaranya : Buruh tani, Petani, Peternak, Tukang kayu, Tukang batu,Penjahit, PNS, Pensiun, TNI/POLRI, Perangkat desa, Pengrajin, Industri kecil, Buruh industri/lainnya. Jenis mata pencaharian penduduk Desa Sea secara rinci dapat dilihat pada Tabel 2.
Tabel 2. Jenis Mata Pencaharian Penduduk Desa Sea Tahun 2016

\begin{tabular}{lrr}
\hline Jenis Mata Pencaharian & Jumlah (Orang) & Presentase (\%) \\
\hline Buruh Tani & 439 & 28,51 \\
Petani & 387 & 25,13 \\
Peternak & 35 & 2,27 \\
Tukang Kayu & 22 & 1,43 \\
Tukang Batu & 115 & 7,47 \\
Penjahit & 18 & 1,17 \\
PNS & 105 & 6,82 \\
Pensiun & 98 & 6,36 \\
TNI/POLRI & 28 & 1,82 \\
Perangkat Desa & 23 & 1,49 \\
Pengrajin & 18 & 1,17 \\
Industri Kecil & 9 & 0,58 \\
Buruh Industri/Lainnya & 243 & 15,78 \\
Tukang Batu & 22 & 1,43 \\
\hline Jumlah & 1,54 & 100 \\
\hline Sumber : Data Diolah Dari Buku Induk Desa Sea 2015
\end{tabular}

Tabel 2. menunjukkan jenis mata pencaharian penduduk Desa Sea serta presentase masing-masing jenis mata pencaharian. Dari Tabel dapat di lihat bahwa jumlah dari mata pencaharian sebagai Buruh Tani berjumlah 439 orang dengan presentase $28,51 \%$ adalah yang terbanyak, dan mata pencaharian sebagai Pengusaha Industri kecil dengan jumlah 9 orang dan presentase $0,58 \%$ adalah yang sedikit.

\section{Karakteristik Usahatani}

Penelitian yang dilakukan terhadap 40 petani responden di Desa Sea yang terdiri dari umur, tingkat pendidikan, jumlah tanggungan keluarga, Profesi lain diluar usahatani tanaman bumbu masak "rampa- rampa campur" luas lahan, status lahan, lamanya usahatani, proporsi tenaga kerja, dan biaya-biaya usahatani.

\section{Tingkat Pendidikan}

Pendidikan merupakan salah satu hal yang sangat penting dalam kehidupan manusia yang merupakan bekal hidupnya. Tingkat pendidikan petani responden dapat dilihat pada Tabel 3.

Tabel 3. Jumlah Petani Responden Tanaman Bumbu Masak "Rampa - Rampa Campur" Berdasarkan Tingkat Pendidikan

\begin{tabular}{lrr}
\hline \multicolumn{1}{c}{ Tingkat pendidikan } & Jumlah (Petani) & Presentase (\%) \\
\hline SD & 7 & 17,5 \\
SMP & 10 & 25,0 \\
SMA \& SMK & 18 & 45,0 \\
S1 & 5 & 12,5 \\
\hline Jumlah & 40 & 100 \\
\hline Sumber : Diolah Dari Data Primer 2015 & &
\end{tabular}


Tabel 3, menjelaskan jumlah dan presentase petani Responden"rampa-rampa campur" berdasarkan tingkat pendidikan. Berdasarkan Tabel 4 dapat dilihat bahwa jumlah petani yang berpendidikan SMA \& SMK adalah yang terbanyak yaitu berjumlah 18 orang dengan presentase $45 \%$ sedangkan tingkat pendidikan Perguruan Tinggi adalah yang paling sedikit yaitu berjumlah 5 orang dengan presentase $12,5 \%$.

\section{Umur Petani}

Umur seorang petani menentukan prestasi kerja atau kinerja orang tersebut, semakin tua umur maka tenaga kerja petani secara fisik akan berkurang, sehingga prestasi kerjanya pun akan menurun. Namun dalam hal ini semakin tua umur tenaga kerja tidak akan berpengaruh pada masalah tanggung jawab justru semakin berpengalaman (Suratiyah dalam Paulus dkk, 2015). Tingkat umur dapat dilihat pada Tabel 4.

\begin{tabular}{|c|c|c|c|c|}
\hline Tabel 4. & $\begin{array}{l}\text { Jumlah dan } \\
\text { Responden }\end{array}$ & Presentase & Umur & Petani \\
\hline Umur & $\begin{array}{r}\text { Jumlah R } \\
\text { (Or }\end{array}$ & $\begin{array}{l}\text { esponden } \\
\text { ang) }\end{array}$ & Pres & $\begin{array}{l}\text { ntase } \\
\text { \%) }\end{array}$ \\
\hline $20-30$ & & 3 & & 7,5 \\
\hline $31-40$ & & 6 & & 15,0 \\
\hline $41-50$ & & 19 & & 47,5 \\
\hline $51-60$ & & 11 & & 27,5 \\
\hline $61-70$ & & 1 & & 2,5 \\
\hline Jumlah & & 40 & & 100 \\
\hline
\end{tabular}

Sumber : Diolah Dari Data Primer 2015

Tabel 4, menjeskan jumlah dan presentase umur petani responden tanaman bumbu masak "rampa-rampa campur," umur petani 41-50 adalah yang terbanyak dengan jumlah 19 orang dan presentase 47,5 sementara umur petani 61-70 adalah tergolong sedikit dengan jumlah 1 orang dan presentasenya 2,5 .

\section{Jumlah Tanggungan Petani Responden}

Jumlah tanggungan keluarga bisa membantu dalam penyediaan tenaga kerja. Untuk lebih jelasnya jumlah tanggungan keluarga petani dapat dilihat pada Tabel 5.
Tabel 5. Jumlah Tanggungan dan Jumlah Responden

\begin{tabular}{lrr}
\hline $\begin{array}{c}\text { Jumlah Tanggungan } \\
\text { (Orang) }\end{array}$ & $\begin{array}{c}\text { Jumlah } \\
\text { Responden } \\
\text { (Orang) }\end{array}$ & Presentase (\%) \\
\hline 2 & 7 & 17,5 \\
3 & 7 & 17,5 \\
4 & 12 & 30,0 \\
5 & 9 & 22,5 \\
6 & 5 & 12,5 \\
\hline Jumlah & 40 & 100 \\
\hline
\end{tabular}

\section{Luas Lahan}

Luas lahan dari petani responden terbagi menjadi dua bagian yaitu: Petani yang memiliki luas lahan mulai dari $30-110 \mathrm{~m}^{2}$ dengan presentase $67,5 \mathrm{~m}^{2}$ berjumlah 27 responden adalah yang paling banyak, dan Petani yang memiliki luas lahan dengan luas mulai dari $115-300 \mathrm{~m}^{2}$ dengan presentase 32,5 berjumlah 13 responden adalah yang paling sedikit seperti yang terlihat pada Tabel 6 .

Tabel 6. Luas Lahan Usahatani Tanaman Bumbu Masak "Rampa-Rampa Campur" yang di miliki Petani Responden

\begin{tabular}{lrr}
\hline Luas Lahan $\left(\mathbf{m}^{\mathbf{2}}\right)$ & $\begin{array}{c}\text { Jumlah Petani } \\
\text { (Orang) }\end{array}$ & $\begin{array}{c}\text { Presentase } \\
(\mathbf{\%})\end{array}$ \\
\hline $30-110$ & 13 & 32,5 \\
$115-300$ & 27 & 67,5 \\
\hline Jumlah & 40 & 100 \\
\hline
\end{tabular}

Tabel 6, menjelaskan bahwa dari 40 petani responden yang memiliki luas lahan $30-110 \mathrm{~m}^{2}$ sebanyak 13 responden dengan presentase 32,5 adalah yang sedikit, sementara petani responden yang memiliki luas lahan $115-300 \mathrm{~m}^{2}$ dengan presentase 67,5 adalah yang paling banyak.

\section{Deskripsi Usahatani Tanaman Bumbu}

Berdasarkan hasil penelitian ini di dapati bahwa petani di Desa Sea masih menggunakan cara tradisional atau sederhana untuk mengusahakan semua jenis tanaman bumbu masak "rampa-rampa campur." Dibawah ini akan di deskripsikan masingmasing dari setiap jenis usahatani tanaman bumbu masak serta perlakuan dari Petani terhadap setiap tanaman bumbu masak tersebut." 


\section{Kemangi}

Petani yang mengusahakan jenis tanaman kemangi menggunakan dua jenis lahan yaitu: Full Area dan Margin Area. Full Area adalah sistim tumpang sari dan Margin Area adalah lahan kosong yang tak terpakai/lahan sisa. Petani membuka lahan dengan dua cara yaitu: Penyemprotan dan Pemarasan, sementara benih atau bibit Petani tidak membelinya ke toko Pertanian, Petani responden hanya meminta benih yang berasal dari tanaman kemangi tua ke sesama Petani. Petani melakukan budidaya dengan cara sederhana yaitu: Taburkan benih secara langsung di lahan yang telah tersedia da nada pula yang membuat penyamaian benih di lahan khusus kemudian dipindahkan ke lahan sesudah benih bertumbuh menjadi bibit yang siap di pindahkan. Petani melakukan pembersihan gulma terhadap tanaman kemangi setiap satu bulan dan tidak ada pemakaian pupuk terhadap usahatani tanaman kemangi. Panen dilakukan sesudah umur tanaman kemangi mencapai satu bulan atau satu bula satu minggu. Panen pertama dilakukan dengan cara memetik pucuk atau mengambil setengah batang, cara ini di lakukan agar tumbuh tunas-tunas baru dan menjadi rimbun dan proses panen selanjutnya bisa lebih banyak lagi. Tanaman kemangi di panen satu kali dalam seminggu sesudah panen pertama dilakukan, untuk jumlah panen tanaman kemangi bergantung pada luas lahan yang di usahakan petani, lahan yang kecil hasi panennya bisa mencapai 250 ikat sementara untuk lahan yang tergolong sedikit luas hasil panennya bisa mencapai 500 ikat. Usia tanaman kemangi bisa bertahan hingga satu tahun tergantung perawatannya. Petani di Desa Sea yang mengusahakan tanaman kemangi hanya dua responden saja yang pernah yang pernah melakukan treatment dengan baik hingga usia tanaman mencapai umur satu tahun. Petani dari 40 responden rata-rata biasa hanya melakukan usahatani kemangi mulai dari 5-7 bulan.

\section{Serai}

Petani yang mengusahakan jenis tanaman Serai menggunakan dua jenis lahan yaitu: Full Area dan Margin Area. Full Area adalah sistim tumpang sari cara ini dilakukan karena tidak ada lagi lahan yang kosong kecuali lahan yang sudah diisi dengan jenis tanaman lain dan. Margin Area adalah lahan kosong yang tak terpakai/lahan sisa biasanya petani menggunakan jenis lahan ini hanya untuk menanam satu jenis tanaman saja. Petani membuka lahan dengan dua cara yaitu: Penyemprotan dan Pemarasan, sementara bibit Petani tidak membelinya ke toko pertanian, Petani responden memperoleh bibit dari rimpang serai induk milik sendiri atau meminta ke sesama Petani. Petani melakukan usahatani tanaman serai dengan cara sederhana yaitu, petani menanam tanaman serai secara langsung di lahan yang telah tersedia. Petani melakukan pembersihan gulma terhadap tanaman serai setiap satu bulan dan tidak ada pemakaian pupuk terhadap tanaman serai. Panen batang serai dilakukan sesudah tanaman serai mencapai umur 3-4 bulan tergantung pada perlakuan petani dan keadaan cuaca. Panen dilakukan dengan memangkas semua batang atau tanpa menyisahkan batang-batang batang halus. Hasil panen batang dari 22 responden rata-rata 80 ikat.

\section{Pandan}

Petani yang mengusahakan jenis tanaman pandan sama dengan petani lain yang menggunakan dua jenis lahan yaitu: Full Area. Full Area adalah sistim tumpang sari ini dilakukan apa bila petani tidak memiliki lahan kosong dan. Margin area adalah lahan kosong yang tidak terpakai seperti kintal rumah atau pinggiran kebun, bentuk lahan semacam ini digunakan hanya untuk menanam satu jenis tanaman saja. Petani membuka lahan dengan cara yang sama yaitu: Penyemprotan dan Pemarasan, sementara bibit atau anakan tanaman pandan Petani tidak membelinya di toko Pertanian, tetapi Petani responden memperoleh bibit yang berasal dari tanaman pandan tua dari sesama Petani dengan cara vegetatif. Petani melakukan usahatani tanaman pandan dengan cara sederhana yaitu, Petani menanam bibit atau anakan tanaman tersebut secara langsung di lahan yang telah tersedia dan lahannya harus dekat dengan sumber air atau daerah yang tingkat kelembapannya tinggi. Petani melakukan pembersihan gulma terhadap usahatani tanaman pandan setiap satu bulan dan tidak ada pemakaian pupuk terhadap tanaman pandan. 
Panen daun pandan pertama dilakukan sesudah umur tanaman pandan mencapai lima sampai enam bulan tergantung perlakuan dari petani. Panen dilakukan dengan menyisahkan 3-4 helai daun yang terdiri dari pucuk dan daun muda, hasil panen daun pandan bergantung pada luas lahan dan banyaknya tanaman yang diusahakan. Petani dari 13 responden yang mengusahakan tanaman pandan di Desa Sea, hasil panennya rata-rata mulai dari 40-50 ikat. Usia tanaman pandan bisa mencapai puluhan tahun tergantung pada pemeliharan dari petani itu sendiri.

\section{Jeruk Purut}

Petani yang mengusahakan jenis
tanaman jeruk purut atau daun jeruk menggunakan jenis lahan Full Area. Petani menanam tanaman jeruk di antara tanaman lain yang di kenal cara tumpangsari, jumlah petani responden yang mengusahakan daun jeruk berjumlah 8 responden saja. Petani membuka lahan dengan dua cara yaitu, penyemprotan dan pemarasan, sementara bibit petani tidak membelinya ke toko pertanian, petani responden memperoleh bibit dari bibit yang tumbuh di sekitar rumah. Petani melakukan menanam tanaman jeruk purut dengan cara sederhana yaitu, tanam bibit secara langsung di lahan yang telah tersedia apa bila petani mempunyai bibit dan jika petani hanya memiliki benih maka Petani membuat penyamaian benih terlebih dahulu di media khusus kemudian dipindahkan ke lahan sesudah benih bertumbuh menjadi bibit. Petani melakukan pembersihan gulma terhadap budidaya tanaman jeruk purut setiap satu bulan dan tidak ada pemakaian pupuk terhadap tanaman jeruk purut. Panen daun jeruk purut pertama dilakukan sesudah umur tanaman jeruk purut mencapai satu sampai dua tahun tergantung pada perlakuan dari petani. Panen dilakukan dengan menyisahkan dua sampai tiga daun yang terdiri dari pucuk dan daun muda. Petani yangmengusahakan tanaman jeruk purut berjumlah 8 responden ini biasa panen daun jeruk (1) satu bulan sekali, hal ini dilakukan agar daun jeruk benar-benar matang, selain itu jumlah panen rata-rata 100 kantong plastik kecil dan usia tanaman bumbu masak juga bisa mencapai puluhan tahun tergantung perawatan.

\section{Kunyit}

Petani yang mengusahakan kunyit menggunakan dua jenis lahan yaitu: Full Area dan Margin Area. Full Area adalah sistim tumpang sari yang lahannya diisi dengan beragam tanaman, sementara Margin Area adalah lahan kosong yang tak terpakai/lahan sisa, bentuk lahan ini di gunakan untuk menanam satu jenis tanaman saja seperti yang diterapkan oleh 4 dari 11 responden yang mengusahakan tanaman kunyit. Petani membuka lahan dengan dua cara yaitu penyemprotan dan pemarasan, sementara benih atau bibit petani tidak membelinya ke toko pertanian, petani responden hanya memperoleh bibit dari umbi kunyit yang tumbuh disekitar rumah atau kebum tua, dan jika tidak ada petani biasa memintanya ke sesama petani. Petani melakukan usahatani tanaman kunyit dengan cara sederhana yaitu menanam bibit tanaman kunyit secara langsung di lahan yang telah tersedia dan tidak perlu melakukan penyamaian. Petani melakukan pembersihan gulma terhadap tanaman kunyit setiap satu bulan dan tidak ada pemakaian pupuk terhadap tanaman kunyit. Panen daun kunyit pertama dilakukan sesudah umur tanaman kunyit mencapai 5-7 bulan, saat panen pertama dilakukan petani menyisahkan $3-4$ helai daun yang terdiri dari pucuk dan daun muda, hal ini di lakukan karena untuk menjaga kestabilan tanaman kunyit tersebut. Petani dari 12 responden yang mengusahakan daun kunyit ratarata jumlah sekali penen yaitu 30 ikat untuk perorangan.

\section{Jenis Tanaman Bumbu Masak, Klasifikasi Responden, Periode Panen dan Hasil Panen Sepanjan Tahun 2016}

Hasil penelitian ini menunjukan bahwa tanaman bumbu masak "rampa-rampa campur" yang di usahakan oleh 40 Petani Responden di Desa Sea ternyata jumlah panen perbulan, dan pertahun tidak menentu karena bergantung pada petani tersebut seberapa banyak yang ia mampu usahakan dan begitu pula hasilnya, seperti yang terjadi sepanjang tahun 2016. Jenis tanaman bumbu masak "rampa-rampa campur" yang di usahakan di antaranya: kemangi, batang serai, daun pandan, daun jeruk, dan daun kunyit . Masing-masing tanaman di atas jumlah Panennya 
berbeda, selain itu periode panen juga berbeda ada yang satu bulan sekali panen, satu bulan dua kali panen dan empat kali panen ada juga yang di panen lima sampai enam bulan dalam setahun tergantung pada jenis tanaman bumbu masak tersebut seperti yang terlihat pada Tabel 7. Tabel 8, menjelaskan bahawa hasil panen tanaman bumbu masak "rampa-rampa campur" dalam kurun waktu satu tahun berbeda-beda yaitu kemangi 4.800 ikat, batang serai 320 ikat, daun pandan 1.440 ikat, daun jeruk 1.200 plastik, dan daun kunyit 960 ikat. Total dari hasil panen tanaman bumbu masak rampa-rampa campur selama 1 tahun adalah 103.360 ikat.

Tabel 7. Hasil Panen Tanaman Bumbu Masak "Rampa-Rampa Campur" dalam Sebulan dan Setahun dari (40) Petani Responden Periode 2016

\begin{tabular}{|c|c|c|c|c|c|c|c|}
\hline \multirow[t]{2}{*}{$\overline{\text { No }}$} & \multirow[t]{2}{*}{$\begin{array}{c}\text { Jenis } \\
\text { Tananan }\end{array}$} & \multicolumn{2}{|c|}{$\begin{array}{c}\text { Panen Hasil } \\
\text { Pertanana }\end{array}$} & \multicolumn{2}{|c|}{$\begin{array}{c}\text { Panen Hasil ke dua } \\
\text { \& Seterusnya }\end{array}$} & \multirow{2}{*}{$\begin{array}{c}\text { Hasil } \\
\text { Panen } \\
- \text { Sebulan } \\
\text { (Ilkat' } \\
\text { plastik) }\end{array}$} & \multirow{2}{*}{$\begin{array}{c}\text { Hasil Panen } \\
\text { Setahun } \\
\text { (Ikat' } \\
\text { plastik) }\end{array}$} \\
\hline & & Bln & Thn & $\begin{array}{c}\text { Minggu } \\
\text { (lkat) }\end{array}$ & $\begin{array}{l}\text { Bulan } \\
\text { (Ikat) }\end{array}$ & & \\
\hline$\overline{1}$ & Kemangi & 1 & - & $4 / 1$ & - & 4.800 & 57.600 \\
\hline 2 & Batang Serai & 34 & - & - & $1 / 3-4$ & - & 5.120 \\
\hline 3 & Dann Pandan & $3-4$ & - & $2 / 1$ & $1 / 2-3$ & 1.440 & 17.280 \\
\hline 4 & Daun Jenuk & $15-24$ & $1,5-2$ & - & $1 / 1$ & 1.200 & 14.400 \\
\hline 5 & Daun Kunyit & 3 & - & $2 / 1$ & - & 960 & 11.520 \\
\hline \multicolumn{2}{|c|}{ Junulah } & - & - & - & - & 8.400 & 103.360 \\
\hline
\end{tabular}

Biaya Usahatani Tanaman Bumbu Masak "Rampa-Rampa Campur"

Berdasarkan hasil penelitian ini menunjukan bahwa besarnya biaya-biaya yang di keluarkan petani responden dalam usahatani relatif beragam, hal ini terjadi karena petani responden mengeluarkan biaya-biaya sesuai dengan kebutuhan petani. Beberapa petani responden bahkan berupaya agar tidak banyak melakukan pembiayaan-pembiaan yang dianggap masih bisa di atasi atau di lakukan dengan cara lain yang tidak perlu mengeluarkan biaya terlalu besar. Petani yang memutuskan untuk tidak banyak mengeluarkan pembiayaan-pembiayaan tersebut di karenakan beberapa hal seperti: petani lain menggunakan tenaga kerja dan lainnya tidak menggunakan tenaga kerja, sebagian petani menggunakan perlengkapan yang uasahatani lengkap lainnya tidak, perlakuan (treatmen) ada yang menggunakan pembasmi hama atau panyakit secara modern ada pula yang tidak menggunakan obat pembasmi hama, penggunaan pupuk tida ada sama sekali, dan tidak ada biaya pembelian benih, dan bibit tanaman yang di usahakan.

\section{Saluran Pemasaran Bumbu Masak "Rampa-rampa Campur"}

Berdasarkan hasil penelitian di dapati bahwa saluran pemasaran bumbu masak "rampa-rampa campur" yang terjadi di Desa Sea ada dua macam yaitu: petani yang jual di lokasi dan petani yang jual di Manado. Petani yang memilih jual hasil panennya di Manado terbagi lagi menjadi beberapa bagian di antaranya: jual ke pasar tradisional (karombasan, bahu, dan jengki), pasar swalayan (freshmart, Golden dan jumbo) serta ke beberapa rumah makan. Berikut adalah gambar 2 yang menjelaskan saluran pemasaran yang terjadi di Desa Sea hingga ke Kota Manado.

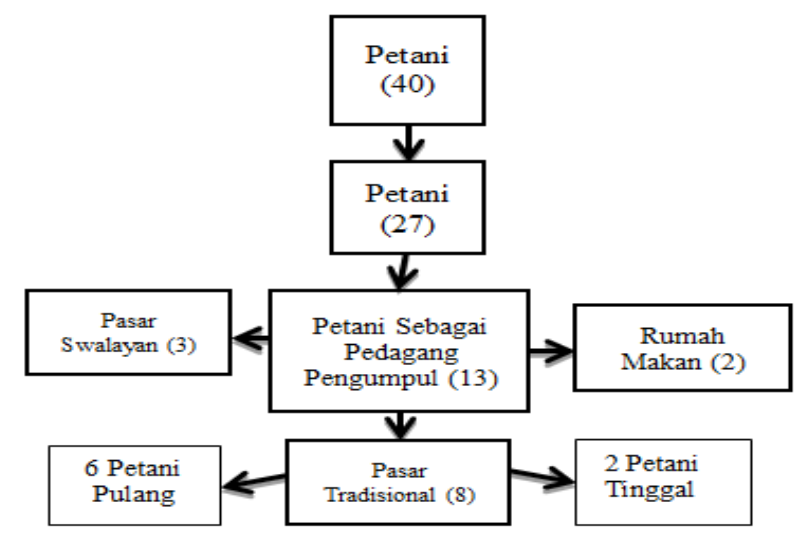

Gambar 2. Saluran Pemasaran Petani Bumbu Masak RRC

Pemasaran bumbu masak "rampa-rampa campur" pada gambar di atas menunjukkan bahwa dari 40 petani responden, terdapat 27 petani yang menjual hasil panennya di lokasi dan 13 petani merangkap sebagai pedagang pengumpul dimana 3 petani menjual ke pasar swalayan, 2 petani menjual ke rumah makan dan 8 petani menjual ke pasar tradisional. Petai dari 8 responden yang jual di pasar tardisional 6 petani hanya lepas saja dan pulang sesudah laku, sementara 2 petani lainnya menetap untuk menjual dalam bentuk "rampa-rampa campur" selain itu ada juga hasil penen seperti sayursayuran, buah dan lainnya yang di jual. 


\section{Biaya Pemasaran Bumbu Masak "Rampa-rampa Campur"}

Hasil penelitian membuktikan bahwa biaya pemasaran menjadi faktor penentu bagi setiap pelaku pasar bumbu masak "ramparampa campur" mulai dari petani sebagai produsen hingga di tingkat pengecer agar proses pemasaran tersebut bisa berjalan dengan lancar. Petani dari 40 responden di Desa Sea tidak semua responden menjual hasil panennya ke Pasar tradisional (karombasan, bahu, dan jengki), dan pasar swalayan (freshmart, dan jumbo) serta ke rumah makan. Pemasaran bumbu masak "rampa-rampa campur" yang terjadi di Desa Sea ada dua macam yaitu ada yang jual di lokasi dan ada juga yang jual ke Manado di beberapa pasar yang telah di sebutkan diatas, petani yang memilih untuk jual hasil panennya di lokasi tidak mengeluarkan biaya sama sekali sementara petani yang memilih untuk jual di Pasar tradisional, pasar swalayan, dan rumah makan hanya mengeluarkan biaya transpotasi dan biaya transportasi biasanya berfariasi hal ini terjadi karena biaya transpotasi di sesuaikan dengan jumlah bahan yang di anggkut dan biaya pemasaran.

\section{Harga Jual Bumbu Masak}

"Rampa-rampa Campur"

Harga jual bumbu masak "ramparampa campur" berfariasi dikarenakan jenis tanaman yang berbeda-beda serta periode panen dari tanaman "rampa-rampa campur" yang berbeda pula. Tanaman bumbu masak yang dijual oleh petani terbagi menjadi 2 jenis yaitu paket bumbu sejenis dan paket "ramparampa campur". Berikut ini adalah harag jual dari paket bumbu sejenis dan paket bumbu "rampa-rampa campur".

\section{Harga Jual di Lokasi}

Berdasarkan hasil penelitian di dapati bahwa dari 40 petani responden 27 di antaranya menjual hasil panen mereka kepada pemborong di lokasi atau tempat petani dalam bentuk satuan ikat perjenis bumbu masak, dan penjualan di lakukan berdasarkan hasil dari kesepakatan kedua belah pihak atau sesuai harga jual yang sedang berlaku. Harga jual bumbu masak yang di jual di lokasi dapat dilihat pada Tabel 8.

Tabel 8. Harga Jual Bumbu Masak (Paket Bumbu Sejenis) di Lokasi Petani

Paket Rampa-rampa Campur

Jenis Bumbu Harga (Rp)

Kemagi, Batang Serai, Daun Pandan,

Daun Jeruk, dan Daun Kunyit

Tabel 8, menjelaskan bahwa harga jual bumbu masak (paket bumbu sejenis) yang dijual di lokasi oleh 27 petani responden dari hasil kesepakatan yang telah disepakati bersama memiliki harga jual harga rata-rata yaitu Rp.2.000.

\section{Harga Jual di Pasar Tradisional}

Dari hasil penelitian di dapati bahwa petani yang terdiri dari 13 responden 8 di antaranya langsung bawa hasil panen atau bahan jualannya ke Manado dan di jual di pasar tradisional, pasar tersebut di antaranya: (karombasan, bahu, dan jengki) sesuai dengan harga jual yang berlaku di pasar. Petani dari 8 responden 6 di antaranya hanya hanya jual dalam bentuk bal dan di dalam (1) bal berisi 100 ikat untuk setiap jenis bumbu, mereka akan pulang sesudah bahan jualannya terjual habis. Harga jual bumbu masak dari 6 responden yang menjual hasil panennya ke pasar tradisional dapat dilihat pada Tabel 9 sebagai berikut.

Tabel 9. Harga Jual Bumbu Masak (Paket Bumbu Sejenis) di Pasar Tradisional Paket Rampa-rampa Sejenis

\begin{tabular}{lr}
\hline \multicolumn{2}{c}{ Paket Rampa-rampa Sejenis } \\
\hline \multicolumn{1}{c}{ Jenis Bumbu } & Harga (Rp) \\
\hline Kemangi & 4.000 \\
Batang Serai & 4.000 \\
Daun Pandan & 4.000 \\
Daun Jeruk & 4.000 \\
Daun Kunyit & 4.000 \\
\hline
\end{tabular}

Tabel 9, menjelaskan bahwa harga jual bumbu masak yang dijual di pasar tradisional yaitu Rp.4.000. 


\section{Pengecer di Pasar Tradisional}

Pengecer di pasar tradisional adalah 2 dari 8 responden (pedagang pengumpul) yang menjual hasil panen mereka di pasar tradisional, mereka sama dengan 6 responden lainnya tetapi mereka memilih untuk tetap bertahan di pasar agar jual bahan yang sudah di paket dalam bentuk "rampa-rampa campur" serta bahan lainnya seperti sayur-sayuran, buah, dan lain sebagainya. Harga jual bumbu masak "rampa-rampa campur" dari Pengecer di pasar tradisional yang jual ke konsumen dapat dilihat pada Tabel 10 sebagai berikut.

Tabel 10. Harga Jual dari Pengecer di Pasar Tradisional

\begin{tabular}{cc}
\hline \multicolumn{2}{c}{ Paket (Rampa-rampa Campur } \\
\hline Jenis Bumbu & Harga $(\mathbf{R p})$ \\
\hline
\end{tabular}

Kemagi, Batang Serai, Daun Pandan,

Daun Jeruk, dan Daun Kunyit

2.000

\section{Harga Jual di Pasar Swalayan}

Hasil penelitian ini membuktikan bahwa 3 dari 13 petani responden yang berperan sebagai pedagang pengumpul membawa hasil panen atau bahan jualannya langsung ke pasar swalayan (Moderen). Hasil panen atau bahan tersebut di jual dalam bentuk bal yang di dalamnya terdiri dari 100 ikat untuk setiap jenis bumbu masak. Harga jual bumbu masak dari 3 petani responden yang menjual hasil panennya ke pasar swalayan dapat dilihat pada Tabel 11.

Tabel 11. Harga Jual Bumbu Masak (Paket Bumbu Sejenis) di Pasar Swalayan

Paket Rampa-rampa Sejenis

\begin{tabular}{lr}
\hline \multicolumn{1}{c}{ Jenis Bumbu } & Harga (Rp) \\
\hline Kemangi & 4.000 \\
Batang Serai & 4.000 \\
Daun Pandan & 4.000 \\
Daun Jeruk & 4.000 \\
Daun Kunyit & 4.000 \\
\hline
\end{tabular}

Tabel 11 menjelaskan bahwa 3 petani responden yang berperan sebagai pedagang pengumpul menjual hasil panen atau bahan jualanya di pasar swalayan dengan harga jual perikat yaitu Rp.4.000.

\section{Harga Jual di Rumah Makan}

Berdasarkan hasil penelitian di dapati bahwa 2 dari 13 petani responden yang berperan sebagai pedagang pengumpul menjual hasil panen atau bahan jualannya langsung ke beberapa Rumah makan yang sudah menjadi langganan mereka di kota Manado. Bahan jualan di bawa ke masing-masing rumah makan sesuai dengan pesanan dari pihak rumah makan tersebut. Bumbu masak di jual dalam bentuk bal maupun satuan ikan di rumah. Harga jual bumbu masak dari petani responden yang menjual hasil panennya ke rumah makan dapat dilihat pada Tabel 12 sebagai berikut.

Tabel 12. Harga Jual Bumbu Masak (Paket Bumbu Sejenis) di Rumah Makan

\begin{tabular}{lr}
\multicolumn{2}{c}{ Sejenis) di Rumah Makan } \\
\hline \multicolumn{2}{c}{ Paket Rampa-rampa Sejenis } \\
\hline Jenis Bumbu & Harga (Rp) \\
\hline Kemangi & 4.000 \\
Batang Serai & 4.000 \\
Daun Pandan & 4.000 \\
Daun Jeruk & 4.000 \\
Daun Kunyit & 4.000 \\
\hline
\end{tabular}

Tabel 12, menjelaskan bahwa 2 dari 12 petani responden yang menjual hasil panen atau bahan jualannya ke rumah makan dengan harga jual perikat yaitu Rp.4.000.

\section{Penerimaan Usahatani}

Total peneriman adalah jumlah produksi dikalikan dengan harga jual yang berlaku (Wilson, 2007 dalam Sumampouw 2015). Penerimaan yang diperoleh petani bumbu masak "rampa-rampa campur" di Desa Sea merupakan hasil perkalian antara jumlah bahan atau satuan ikat yang diperoleh dikalikan dengan harga jual yang berlaku (Terlampir pada lampiran 1). Perhitungan penerimaan dari petani responden "ramaparampa campur" di Desa Sea yaitu:

$$
\text { Rumus : } \mathbf{T R}=\mathbf{Q} \times \mathbf{P}
$$


Dimana :

$\mathrm{TR}=$ Total revenue/total penerimaan

$\mathrm{Q}=$ Quantity/Jumlah panen (ikat)

$\mathrm{P}=$ Price/harga jual bumbu masak

Hasil perhitungan penerimaan petani "rampa-rampa campur" yang ada di Desa Sea yaitu rata-rata penerimaan Rp.643.450, adalah hasil dari sekali melakukan penjualan.

\section{Pendapatan Usahatani}

Pendapatan usahatani adalah selisih antara penerimaan dan semua biaya dalam meningkatkan pendapatan, maka petani harus berusaha untuk meningkatkan hasil produksi agar memperoleh peningkatan pendapatan dengan memaksimalkan faktor produksi terutama tenaga kerja yang merupakan salah satu faktor produksi yang sangat mempengaruhi dalam usahatani keluarga (Soekartawi, 1995 dalam Pulus, dkk, 2015). Pendapatan usahatani bumbu masak "rampa-rampa campur" diperoleh dengan mengunakan perhitungan sebagai berikut:

Dimana :

$$
\text { Rumus : } \mathbf{I}=\mathbf{T R}-\mathbf{T C}
$$

$$
\begin{aligned}
& \mathrm{I}=\text { income }(\text { pendapatan }) \\
& \mathrm{TR}=\text { total revenue }(\text { penerimaan }) \\
& \mathrm{TC}=\text { total cost } \text { (biaya) }
\end{aligned}
$$

Rata-rata pendapatan yang diperoleh petani bumbu masak "rampa-rampa campur" di Desa Sea yaitu Rp.461.104.

\section{KESIMPULAN DAN SARAN}

\section{Kesimpulan}

Kesimpulan dari penelitian adalah sebagai berikut:

1. Usahatani tanaman bumbu masak "ramparampa campur" yang diusahakan oleh petani di Desa Sea, belum sepenuhnya menggunakan sistem usahatani yang bersifat modern tetapi masih menggunakan cara pengolahan yang tradisional atau sederhana.
2. Biaya usahatani yang dikeluarkan petani responden masih bersifat implisit hal ini dikarenakan petani responden hanya mengeluarkan biaya usahatani sesuai dengan kebutuhanya.

3. Pemasaran yang terjadi di Desa Sea hingga ke kota manado pada petani bumbu masak "rampa-rampa campur" yaitu: Petanipedagang pengumpul-pengecer-konsumen akhir.

4. Biaya pemasaran yang di keluarkan untuk memasarkan bumbu masak "rampa-rampa campur" oleh petani juga masih bersifat implisit, karena bergantung pada tempat pemasaran serta jumlah bahan yang diangkut.

5. Pendapatan yang diperoleh petani dari hasil penjualan bumbu masak "ramparampa campur" dan paket bumbu sejenis hasil dari sekali melakukan penjualan terbilang untung.

\section{Saran}

Berdasarkan kesimpulan di atas, maka saran dari penulis yaitu:

1. Guna meningkatkan pendapatan petani maka usahatani tanaman bumbu masak "rampa-rampa campur" yang di usahakan di Desa Sea harus lebih di tingkatkan lagi dengan menggunakan sistim usahatani yang bersifat moderen agar jumlah produksinya meningkat.

2. Biaya usahatani yang di keluarkan petani dalam usahataninya selama ini harus di pertahankan.

3. Pemasaran yang terjadi di Desa Sea hingga ke kota manado pada petani bumbu masak "rampa-rampa campur" harusnya ada juga relasi tetap di pasar tempat dimana petani jual hasil panen. 


\section{DAFTAR PUSTAKA}

Azzaino, dalam Gyfriah 2004. Makalah Pengantar Tataniaga Pertanian. ilmu Sosial Ekonomi Fakultas Pertanian IPB. Bogor. Diakses pada 29 November 2005.

Broto, h. Burki, S.J. S, Yusuf 2008. Pembangunan pertanian.PT. Bina Ilmu. Surabaya.Diakses Pada 20 Mei 2011.

Djunaidi,2009,"Strategi Bisnis Usaha Kecil Dan Menengah"(UKM) Penelitian dilaksanakan di Kecamatan Ngadiluwih KabupatenKediri. Diakses pada 7 Agustus 2010.

Gustiyana, 2003. Pengantar Ekonomi Pertanian. LP3ES. Jakarta.

Harianto, dalam pertiwi 2012.Kemangi Sebagai Bahan Baku Industri.Diakses pada 30 september 2012.

Hazan, 2001:7.Analisis deskriptif dengan judul Teori Analisis Deskriptif. Anda bisa book mark halaman ini dengan URL http://statistik ceria. blogspot. co.id/2012/01/teori-analisisdeskriptif.html AnonymousJuly 21, 2012 at 11:05 PM.

Hermanto, 1993. Ilmu Usaha Tani. Swadaya. Jakarta. Pembangunan Pedasaan IPB Bogor.

Hermanto, 1994. Pendapatan Marjinal.Pt. Bina Aksara, Jakarta. Diakses Pada Tanggal 12 Juni 2015.

Kotler, 2002.Kajian Sistem Pemasaran Berbagai Sayuran Dataran Rendah Di Pulau Lombok.journalAgroteksos Volume 6 nomor 1, Edisi April 1996. Fakultas Pertanian Universitas Mataram.

Kotler, p. 1980, Marketing Management, New Jersey: Printice Hall, Inc. Englewood Dalam Soekartawi 2003. Agribusnis Teori Dan Aplikasinya.
Limbong, D,T, M. Maray, M, Ratulangi, C. Rante. R. Dien, M. Hamming, M. Shepard And G. Carnner(2006). Pengantar Tataniaga Pertanian. Jurusan Ilmu-ilmu Sosial Ekonomi Pertanian. IPB. Bogor. 183.

Panduan Budidaya Jeruk Purut http://selaparanglanang. blogspot.co.id 12013/04/ panduan- budidaya- jerukpurut. html. Diakses pada 30 April 2013.

Rahayu, 2000. Laporan Praktikum Bumbu dan Rempah.blog.upi.edu /2015/11/08/ laporan -praktikum-Bumbu dan rempah/ (diakses pada 6 Juli 2016).

Rizky, 2010. Makalah Bumbu Dan Rempah. .http:// zaythecllas.blogspot. com(diakses pada 10 Maret 2004).

Sembel, DT., M. Maray, M. Ratulangi, c. Rante.R, Dien, M. Hammig, m. Shepard and g. Carner, "2006, Annual Report IPM CRSP Sam Ratulangi University Manado".

Setyaningsi,2003.Bumbu dan Rempah Komoditi Pertanian. Dalam Majalah Pertanian. No. 3.Tahun 1981 / 1982.464 .http:// zaythecllas.blogspot. com(diakses pada 5 Mei 2004)

Soekartawi, 1987.Seuntai Usahatani Indonesia.Raja wali. Jakarta. 1988. Prinsipdasar Komunikasi Pertanian. Universitas Indonesia.Press. Jakarta.113.

Soekartawi, dalam Singal (2011). Analisis Usaha Tani Kelapa.Fakultas Pertania Unsrat Manado.

Wati, 2010. Makalah Serai Dalam Rumah Tangga . Fakultas Ekonomi. Universitas Gajah Mada Yogyakarta.Diakses pada 10 Juni 2010.

Winardi,1990. Azas- azas Marketing.Penerbit Alumni. Bandung. 464 .http:// zaythecllas.blogspot. com(diakses pada 25 mei 2016) 